\title{
The Drinking Bird
}

\section{Dianne Millett}

My MaMa had a tipping bird. It had a stuck-on face and stupid smile. It looked like a cross between an ostrich and something out of a chemistry set. The oily red stuff that filled its glass-balled belly wasn't Cottees. It looked wrong. And I didn't trust the long straw neck or its yellow plastic chicken legs either; the same way I didn't trust chocolate laxative and cough syrup that was supposed to taste like lollies. It wore a top hat and tie but never went anywhere special, except when we came to visit, then it would be carefully placed on the bench so we could watch it up close. Mostly it sat high up on the window sill looking too clever for its own good.

My sweet MaMa, my Grandmother who smelled of violets, lavender and lily of the valley on different days, wanted us to call it Jerry. It didn't take. It was always called The Bird.

The Bird was lead to water and made to drink. It's true. A glass 
of water was placed before it and then an adult finger would give its head a little push. And it would tip, appear to drink, rock back, hesitate, almost over balance, then drop forward, wait a second, then do it all over again. It was only the possibility of failure before the inevitable that made it interesting, almost hypnotizing, but only for a little while - about the attention span of a child...

\section{$\infty \infty$}

Too many people arranged Just So today. Sat before their respective cups, sticking their noses in. Following some set determination towards a weighted outcome. Playing at Rockaby; backwards and forwards. Others nodding them on. All just the same. Nothing changing from year to year, except maybe a little fading, or the sad loss of a tail feather...

It was me who smashed that bloody bird. Really flipped it and on purpose. I remember the liquid in its belly thicker than water, puddled on the kitchen floor. Its head rolled under the fridge and had to be poked out with a stick. The worst of it was a chemical smell that stayed for ages, even after all the mopping up. Nasty, dirty bird. Made in China. I was glad to see it go. 